\title{
MONITORING PROBLEMS OF ROSTOV-ON-DON CITY AREA SOIL POLLUTION
}

\author{
L. Pustovaya, A. Borman, Z. Vatutin, S. Khlebunov \\ Don state technical university. Rostov-on-Don, Russian Federation \\ science-almanac@mail.ru
}

The paper presents the research results of the territory contamination of the shooting and stand complex of the North Caucasus Military District Military Hunting Society, the interregional sports organization, operating in Rostov-on-Don since 1992. This object is identified as a source of contacting environment contamination with lead and its compounds, since the lead shot is used at the complex shooting areas. Series of soil samples were selected at different distances from the targets in accordance with the requirements of regulatory documents, taken from the surface layer to the depth of $10-15 \mathrm{~cm}$. The acidity level was measured, in the aqueous extract, which on average had a $\mathrm{pH}$ value of $\sim 7$ corresponding to a neutral medium. Visually lead shot of various degradation degree is found in the samples. 2,5 grams of lead were extracted mechanically from $1 \mathrm{~kg}$ of the composite sample, which significantly exceeds the established standard $(0.032 \mathrm{~g} / \mathrm{kg})$. A qualitative chemical analysis of aqueous extract confirmed the presence of lead compounds. Quantitative chemical analysis of lead mobile acid-soluble forms was carried out by inversion voltammetry according to the procedure of MU 08-47 / 56 on the TA-Lab device in extracts obtained by treating the $1 \mathrm{M}$ of soil sample with $\mathrm{HNO}_{3}$ solution. The average concentration of lead ions in the selected samples was $65 \mathrm{~g} / \mathrm{kg}$. Considering that apartment block is situated near the contaminated area, the necessity of its clearing from pollutant is evident. It was suggested to recultivate the top layer of the soil by removing it and complex processing, firstly by a physical method to extract metallic lead, and then by reagent to remove lead compounds. The composition and concentration of reagents depends on the type of soil and the level of its contamination with lead.

Key words: monitoring, soil contamination, heavy metals, lead, recultivation, shooting area, lead shot.

[Пустовая Л.Е., Борман А.Э., Ватутин З.Н., Хлебунов С.А. Проблемы мониторинга загрязнений почвы городских территорий г. Ростова-на-Дону]

Приводятся результаты исследования загрязнения территории стрелково-стендового комплекса военно-охотничьего общества Северо-Кавказского Военного Округа - межрегиональной спортивной общественной организации (ВОО СКВ-МСОО), функционирующего в г. Ростове-на-Дону с 1992 г. Этот объект идентифицирован как источник загрязнения контактирующих сред свинцом и его соединениями, так как на стрелковых площадках комплекса используется свинцовая дробь. Были отобраны серии проб почвы на различном расстоянии от мишеней в соответствии с требованиями нормативных документов, взятые с поверхностного слоя до глубины 10-15 см. В водной вытяжке измеряли уровень кислотности, который в среднем имел значение $\mathrm{pH} 7$, соответствующее нейтральной среде. Визуально в пробах обнаружена свинцовая дробь в разной степени деградации. Из 1 кг составной пробы механическим путем извлекли 2,5 г свинца, что существенно превышает установленный норматив $(0,032$ г/кг). Качественный химический анализ водной вытяжки подтвердил наличие соединений свинца. Количественный химический анализ подвижных кислоторастворимых форм свинца проводили методом инверсионной вольтамперометрии по методике MY 08-47/56 на приборе TA-Lab в вытяжках, получаемых обработкой образца почвы $1 \mathrm{M}$ раствором $\mathrm{HNO}_{3}$. Средняя концентрация ионов свинца в отобранных пробах составила 65 г/кг. Учитывая, что рядом с загрязненной территорией находится жилая застройка, очевидна необходимость ее очистки от поллютанта. Предложено рекультивировать верхний слой почвы путем его изъятия и комплексной обработки сначала физическим методом для извлечения металлического свинца, а затем реагентным - для удаления соединений свинца. Состав и концентрация реагентов зависит от типа почвы и уровня ее загрязнения свинцом.

Ключевые слова: мониторинг, загрязнение почв, тяжелые металлы, свинец, рекультивация, стрельбище, свинцовая дробь.

Larisa E. Pustovaya - candidate of Chemistry, associate professor. Don state technical university. Rostovon-Don, Russian Federation.

Anna E. Borman - student. Don state technical university. Rostov-on-Don, Russian Federation. 
Zakhar N. Vatutin - student. Don state technical university. Rostov-on-Don, Russian Federation.

Sergey A. Khlebunov - candidate of technical sciences, associate professor. Don state technical university. Rostov-on-Don, Russian Federation.

Пустовая Лариса Евгеньевна - кандидат химических наук, доцент. Донской государственный технический университет. г. Ростов-на-Дону, Россия.

Борман Анна Эдвиновна - студент. Донской государственный технический университет. 2. Ростов-на-Дону, Россия.

Ватутин Захар Николаевич - студент. Донской государственный технический университет. 2. Ростов-на-Дону, Россия.

Хлебунов Сергей Анатольевич - кандидат технических наук, доцент. Донской государственный технический университет. г. Ростов-на-Дону, Россия.

Efforts undertaken by the government of the Russian Federation and city authorities to create an enabling environment in cities and to improve the efficiency of urban resource use, greatly contribute to the development of the Russian economy, but not sufficiently and far from the necessary one and, moreover, the maximally possible. According to the classification of the Russian Federation Regional Development Ministry, Rostov-on-Don takes the tenth place according to the population number among Russian cities and has environmental problems typical for large cities. According to the official data, published by the Rostov region government [2] one marks the higher level of atmosphere air contamination with suspended substances (dust), fluorine hydride, soot, formaldehyde and nitrogen dioxide in Rostov-on-Don. The basic contribution to the outbreaks from stationary sources in the atmosphere are deposited by MUE "Teplocommunenergo", JSC "TGK-8" the branch "Rostov city generation", LLC "Combine plant "Rostselmash", LLC "Rostov casting plant", JSC "RHPC "Rostvertol", the branch of NCRW JSC "RRW", LLC "Rostselmashenergo", LLC “Aristotel”, CHSC "Yug Rusi”, JSC “KOMAT”, JSC “GPZ 10”.

SC "Vodokanal Rostov-on-Don" is the main contaminant of the river Don artery. The level increase of brinishness and turbidity is marked. The river lost its former recreational significance. It is not possible to exclude unauthorized discharge of sewage into the river Temernik and beams (stream) Bezymyannaya, as well as unauthorized landfills. There is also a tendency to deterioration of drinking water quality, especially on microbiological indicators in the summer period. Precipitation (snow, rain with snow, rain) have a slightly acidic environment. The average annual air temperature is above the norm on $1.0-1.9^{\circ} \mathrm{C}$. Researches of the state monitoring service showed a stable degradation of soils. Unfortunately, continuous monitoring of the ecological and toxicological situation in the Rostov region, though is considered to be one of the priority tasks of the agrochemical services of the region, but its objects are only soils of agricultural land, the lands of urban areas are not included in it. The World Health Organization regards soil infection with lead, mercury and cadmium to be the most dangerous of all. This predetermines research topicality of lead content in soils of Rostov-on-Don.

Work results analysis of regional authorities ecological inspection and state observation service for the environment condition allows drawing a conclusion about that Rostov-on-Don industrial enterprises are not the suppliers of above norm lead income. However, unauthorized dumps of lead-containing waste, or specific objects that are not within the scope of state control can be the source of this pollutant. In this paper, the shooting and stand complex of the Military Hunting Society of the North Caucasus Military District, an interregional sports non-governmental organization (MHS NCMD ISSO), operating in Rostov-on-Don since 1992, was defined as such an object. The complex includes 6 shooting sites for trap-shooting and 2 sites for bullet shooting. The platforms are 
equipped with modern missile equipment and allow the following shooting disciplines to be implemented: skeet, trap, d-trap, sporting [18], which use lead shot.

The decision about complete prohibition of lead shot using at hunt in all advanced countries was accepted in the beginning of the 90-s in connection with ecological standards stiffening on environment contamination with lead. In the early 2000s a number of countries imposed a ban on the use of lead shot also for sports shooting. But the features of trap-shooting do not allow replacing the lead shot with steel [17]. In our country, great attention is paid to the development of Olympic sports, so it is necessary to develop ways to operate shooting areas, eliminating pollution of the environment with lead for the successful development of trap-shooting in Russia. At the same time, the Russian government tightens standards for environmental pollution by lead. In accordance with Hygienic standards [3], the maximum permissible concentration (MAC) of lead in the soil of settlements in Russia is $32 \mathrm{mg} / \mathrm{kg}$. According to [16], lead refers to the first class of hazard of chemical pollutants. The maximum indicator of harmfulness of lead is $260 \mathrm{mg} /$ $\mathrm{kg}$ [3]. The danger of soil contamination with lead is determined primarily by the level of its possible negative impact on contacting media (water, air), food products and directly or indirectly on humans, as well as biological soil activity and self-purification processes [11, 14]. Considering that the apartment block is situated in $50 \mathrm{~m}$ from the polygon, the research of lead content on its territory considers to be topical.

To carry out soil monitoring at the polygon, a series of soil samples were selected at different distances from the targets in accordance with the requirements of normative documents [4-6], taken from the surface layer to a depth of $10-15 \mathrm{~cm}$. Visual inspection showed that the soil structure is loose, homogeneous, the color is black. Using the $\mathrm{pH}$ meter, the acidity of the soil was determined from the aqueous extract according to the procedure [7]. On the average, the acidity of the soils is $\mathrm{pH}=7$. These data make it possible to classify the soil of the polygon as chernozem.

Lead shot was collected and weighed in selected samples by mechanical extraction. The traces of various degradation degree are visually detected that points to translocation transition of lead to the soil in the form of lead compounds. On the average about $2,5 \mathrm{~g}$ of metal lead were extracted from the $1 \mathrm{~kg}$ of the soil in various samples. For the detection of lead compounds presence the soil was cultivated during 12 hours with acetic acid solution with $\mathrm{pH}=5,5$, imitating rainwater. After the settling the solution was drained through decantation and qualitative reactions to lead cations with silver iodides were conducted:

$$
\begin{array}{ll}
\mathrm{Pb}^{2+}+2 \mathrm{I}^{-} \rightarrow & \begin{array}{l}
\mathrm{Pbl}_{2} \\
\text { colorless }
\end{array} \\
\text { yellow }
\end{array}
$$

A characteristic yellow coloration was observed. Thus, the preliminary experiment showed that the contamination with lead and its compounds at the shooting range is of a sufficiently high level, so it is necessary to clarify its content and develop measures to reduce its negative impact on the environment. It is necessary to determine the area of contamination to develop specific recommendations. To do this by numerous and expensive qualitative chemical analysis conducting is economically costly, that is why it is advisably to preliminary build mathematical model of lead shot dispersion and calculate the most probable places of lead shot accumulation at the concrete polygon.

The literature overview showed that there are mathematical models, describing ballistics of shot flight from the shot to the target, or its destructive properties in the organism. The shot behavior beyond the hitting area of damage at flight is described only by some authors piecewise, while the data of the shot behavior vary greatly. Thus, according to one data the max ordinate for shot charge No $7-165 \mathrm{~m}$, according to the other sources $-250 \mathrm{~m}$ [2, 8-10]. Preliminary calculations on dispersion and shot sheaf width spread showed that maximum lead shot pollution zone is situated on $180 \mathrm{~m}$ from the 
shooter starting position and $80 \mathrm{~m}$ in width, several probes, united in one jointed, were selected on this area. To determine the concentration of lead compounds in the soil, the inversion voltammetry method was used according to the procedure of MU 08-47 / 56 on the TA-Lab. The mobile acid-soluble forms of heavy metals, including lead $\mathrm{Pb}$, are determined in the extracts of $1 \mathrm{M} \mathrm{HNO3}$. To this end, a soil sample weighing $5 \mathrm{~g}$ was weighed with an accuracy of $+/-0.1 \mathrm{~g}$ and placed in a conical flask with a capacity of 200 $\mathrm{cm} 3,50 \mathrm{~cm} 3$ of $1 \mathrm{M} \mathrm{HNO} 3$ was added to the sample. The received suspension was shaken on the rotator during 1 hour and infused during the 24 hours, in the closed flask. The extract was then filtered through a dry fold filter "white tape", pre-washed with $1 \mathrm{M}$ HNO3. In connection with the high sensitivity of the voltammetric method, the degree of dilution of the extract was determined experimentally, since the concentration of lead in it was significantly higher than the background. For the analysis, $0.01 \mathrm{ml}$ of extract was taken per $200 \mathrm{ml}$ of distilled water. The average concentration of lead ions in the selected samples was $65 \mathrm{~g} / \mathrm{kg}$, which many times exceeds the established norms $(0.032 \mathrm{~g} / \mathrm{kg})$. Considering that apartment block is situated near the contaminated territory, it is necessary to clear it from pollutant.

In Russia, works on the rehabilitation of heavily polluted areas are not practically carried out due to low environmental and economic efficiency. Only in case of high contamination degree some physical methods are applied, such as restriction of their migration in the contact environments, impoverishment, verification, extraction and disposal of contaminated soil layers. From chemical methods one can mark lime treatment of acid soils, placement of mineral and organic fertilizers, usage of zeolite, humic medications and other absorbents for lead mobility decrease in the soil. It is also possible to extract lead from soils by biological methods with the help of microorganisms, cultivation of plants capable of accumulating lead in large quantities, followed by their removal from the territory, processing or disposal. As a rule, combined methods have the most efficiency. For reclamation of lead-polluted territory, one proposes, for this case, to remove the topsoil layer to a depth of $15 \mathrm{~cm}$ and extract metallic lead and its compounds from it, using the process proposed in the Peterson patent (USA, 1977) [13] after its hardware modernization and refinement.

The idea is concluded in the soil grinding, mixture it with water, obtaining suspension and extraction of lead, fell on the ground. Water after settling is used repeatedly, the soil can be returned to its original location. Lead can be re-started for melting and production of shot. Further into the suspended soil, we suggest adding a reagent that transfers lead contained in the soil as insoluble compounds to soluble forms, after settling, drain the water for reagent treatment, removing lead compounds from it. After centrifugation, the water is reused in the cleaning process. The composition and concentration of reagents depends the soil type and the level of its contamination with lead. Thus, it was experimentally shown that contamination with lead in hazardous quantities takes place at the shooting polygon. The methods of contamination zone determination and the method of polygon soils rehabilitation are offered [15].

\section{Лumepamypa}

1. Алексеев Ю.В. Тяжелые металлы в почве и растениях М., 1987.

2. Арбузов И.А. Математический анализ дробового выстрела. Санкт-Петербург, 2015.

3. ГН 2.1.7.2041-06 Предельно допустимые концентрации (ПДК) химических веществ в почве. Гигиенические нормативы

4. ГОСТ 17.4.3.01-83 Охрана природы. Почвы. Общие требования к отбору проб. 
5. ГОСТ 17.4.4.02-84 Охрана природы. Почвы.

6. ГОСТ 28168-89 Почвы. Отбор проб.

7. ГОСТ 26483-85 Почвы. Приготовление солевой вытяжки и определение ее рН по методу ЦИНАО.

8. Крейцер Б.А., Степанов И.П. Дробовой выстрел. М., 1959.

9. Лисицын А.Ф. Вероятностные расчеты расстояния выстрела по диаметру рассеивания дроби Судебно-медицинская экспертиза. 1974. №2.

10.Марков Е.М., Вдовин А.Ю., Егоров С.Ф. Разработка модели дробовой осыпи для оценки равномерности с учетом параметров стрельбы. Вестник ИжГТУ им. М.Т. Калашникова. 2013. №2 (58).

11.Месхи Б.Ч., Пустовая Л.Е., Богданова И.В., Хлебунов С.А. Современные проблемы безопасности. Донской государственный технический университет. Ростов-на-Дону, 2011.

12.Месхи Б.Ч., Пустовая Л.Е., Баян Е.М. Надзор и контроль в сфрере экологической безопасности. Ростов-на-Дону, 2017

13.Петерсон Ф. К. Патент США 4 039433, 2 августа 1977 г.; фрирма «К. Хагер энд Соне Хиндж Мануфэтуринг Компании

14.Пустовая Л.Е., Месхи Б.Ч. Методы и приборы контроля окружающей среды. экологический мониторинг. Ростов-на-Дону, 2008.

15.Пустовая Л.Е., Ватутин 3.Н. Мониторинг состояния почв стрелковостендового комплекса г. Ростова-на-Дону. Ростов-на-Дону, 2017.

16. СанПиН 2.1.7.1287-03 Санитарно-эпидемиологические требования к качеству почвы

17.http://www.hunt-dogs.ru/netoksichnaya_drob/

18.http://вооскво.pqp

\section{References}

1. Alekseev Yu.V. Heavy metals in soil and plants M., 1987.

2. Arbuzov I.A. Mathematical analysis of a shot. St. Petersburg, 2015.

3. HN 2.1.7.2041-06 admissible concentration limit (ACL) of the chemical substances in soil. Hygienic regulations.

4. SS 17.4.3.01-83 Conservancy of nature. Soil. General requirements to sample taking.

5. SS 17.4.4.02-84 Conservancy of nature. Soil.

6. SS 28168-89 Soil. Sample taking.

7. SS 26483-85 Soil. Preparation of salt extract and determination of its $\mathrm{pH}$ according to CIASNE.

8. Kreitser B.A., Stepanov I.P. Shot. M., 1959.

9. Lisitsyn A.F. Probablistic calculations of shot distance according to the diameter of shot dispersion forensic tests. No 2.

10. Markov E.M., Vdovin A.Yu., Yegorov S.F. Development of shot screes model for equability estimation including the firing parameters. Vestnik of Izhevsk state university of M.T. Kakashnikov. 2013. No2 (58).

11. Meskhi B.Ch., Pustovaya L.E., Bogdanova I.V., Khlebunov S.A. The modern safety problems. Don state technical university. Rostov-on-Don, 2011.

12. Meskhi B.Ch., Pustovaya L.E., Bayan E.M. Supervision and control in the sphere of ecological security. Rostov-on-Don, 2017

13. Peterson F. K. USA patent 4 039433, 2 of August 1977; firm "K.Khager and Sone Khindge Manufacturing Company" 
14. Pustovaya L.E., Meskhi B.Ch. The methods and inspection tools of the environment. Ecological monitoring. Rostov-on-Don, 2008.

15. Pustovaya L.E., Vatutin Z.N. Monitoring of soil condition of Rostov-on-Don shootingstand complex. Rostov-on-Don, 2017.

16. SanPin 2.1.7.1287-03 sanitation-and-epidemiological requirements to the soils quality

17. http://www.hunt-dogs.ru/netoksichnaya_drob/

18. http://вооскво.pq 